\title{
Priority Areas for Establishing National Forests in the Brazilian Amazon
}

\author{
$\underline{\text { Adalberto Veríssimo, Mark A. Cochrane, Carlos Souza Jr., and Rodney Salomão }}{ }^{1}$
}

\begin{abstract}
Brazil will benefit if it gains control of its vast Amazonian timber resources. Without immediate planning, the fate of much of the Amazon will be decided by predatory and largely unregulated timber interests. Logging in the Amazon is a transient process of natural resource mining. Older logging frontiers are being exhausted of timber resources and will face severe wood shortages within $5 \mathrm{yr}$. The Brazilian government can avoid the continued repetition of this process in frontier areas by establishing a network of National Forests (Florestas Nacionais or Flonas) to stabilize the timber industry and simultaneously protect large tracts of forest. Flonas currently comprise less than $2 \%$ of the Brazilian Amazon $\left(83,000 \mathrm{~km}^{2}\right)$. If all these forests were used for sustainable logging, they would provide less than $10 \%$ of the demand for Amazonian timber. To sustainably supply the present and near-future demand for timber, approximately $700,000 \mathrm{~km}^{2}$ of the Amazon forest needs to be brought into well-managed production. Brazil's National Forest Program, launched in 2000, is designed to create at least $400,000 \mathrm{~km}^{2}$ of new Flonas. Objective decision-making tools are needed to site these new national forests. We present here a method for optimally locating the needed Flonas that incorporates information on existing protected areas, current vegetation cover, areas of human occupation, and timber stocks. The method combines these data in a spatial database that makes it possible to model the economic potential of the region's various forests as a function of their accessibility and timber values while constraining model solutions for existing areas of protection or human occupation. Our results indicate that $1.15 \times 10^{6} \mathrm{~km}^{2}$ of forests $(23 \%$ of the Brazilian Amazon) could be established as Flonas in a manner that will promote sustainable forest management; these Flonas would also serve as buffer zones for fully protected areas such as parks and reserves.
\end{abstract}

\section{INTRODUCTION}

The Brazilian Amazon contains nearly a third of the world's tropical forests (Skole and Tucker 1993). These forests play a vital role in the water and carbon cycles as well as in regional and global climates (Salati and Vose 1984, Shukla et al. 1990, Skole and Tucker 1993, Houghton et al. 2000). Amazonian forests may also support the richest collection of biodiversity in the world (Schneider et al. 2000). Long-term conservation of biodiversity and natural resources requires the establishment of sustainably managed production forests as a vital complement to fully protected parks (Frumhoff 1995, Gascon et al. 1998, Schneider et al. 2000).

The Brazilian government is planning major infrastructure projects that will dramatically increase access to the natural resources of the Amazon forest. From 2000-2007, the government plans to invest a total of U.S. $\$ 40$ billion to vastly expand the region's transportation system and power grid (Laurance et al. 2001). Concurrently, timber production is expected to increase in response to the growing domestic and international demand for Amazonian wood. The Amazon is well positioned to dominate the tropical timber trade in the 21st century (Uhl et al. 1997). Balancing this scenario is the government's stated commitment to developing a new forest policy based on well-managed production within its expanded system of national forests or Florestas Nacionais (Flonas). In addition, the government has announced plans to protect biodiversity by turning $10 \%$ of the Amazon into fully protected parks and biological reserves.

Timber extraction is a major land-use activity in the Brazilian Amazon, representing 90\% of Brazil's native wood production (Veríssimo and Smeraldi 1999). Although timber extraction is usually selective in that only a few valuable trees are harvested per hectare (Uhl et al. 1997), most logging is done without any 
management. The effects of unmanaged selective logging include increases in fire susceptibility (Holdsworth and Uhl 1997), damage to nearby trees and soils (Johns et al. 1996, Veríssimo et al. 1992), the risk of extirpating local species (Martini et al. 1994), and carbon emissions (Houghton 1995). Many forests are revisited several times as loggers return to harvest additional tree species that become lucrative when regional timber markets develop (Uhl et al. 1997, Schneider et al. 2000). These forests become very degraded and may have $40-50 \%$ of their canopy cover removed during these logging operations (Uhl and Vieira 1989, Veríssimo et al. 1992). In addition, logged forests frequently burn (Uhl and Buschbacher 1985). Return logging and fire can combine to dramatically change forest structure, resulting in extensive invasion of vines and grasses (Uhl and Kauffman 1990, Veríssimo et al. 1992, Cochrane and Schulze 1999, Cochrane et al. 1999).

Frontier logging operations catalyze deforestation by opening roads into unoccupied government lands and protected areas that are subsequently colonized by ranchers and farmers (Veríssimo et al. 1995). At present, the exhaustion of timber in older frontier areas is causing a chaotic migration of loggers to new frontier areas in western Pará and southern Amazonas. Given the rate of expansion of the Amazonian timber industry, a coherent system of forest management, put in place now, would promote conservation and help achieve sustainable production. In contrast, the current model of largely illegal logging followed by unplanned settlement and widespread forest degradation will lead to biodiversity losses and unsustainable timber production across the Amazon Basin (Veríssimo et al. 1995, Uhl et al. 1997), with logging becoming another boom-and-bust economic activity in Brazil, as it has in tropical Africa and Asia (Vincent 1992). Unconstrained activities of this type have already exhausted resources and devastated forests throughout much of the southern Amazon (Gascon et al. 1998, Schneider et al. 2000).

It is possible to manage Amazonian forests for sustainable timber production if proper planning and management efforts are made (Barreto et al. 1998). The amount of managed timber lands rose from almost nothing in 1993 to nearly a million hectares in 1999. Most loggers would actually prefer to operate within a stable system of defined rules and secure land tenure (Schneider et al. 2000). To increase the range of its forest management activities, the Brazilian government has decided to vastly expand its system of
Flonas. These working forests are sustainable-use conservation units whose purpose is to produce goods (timber and nontimber products) while maintaining environmental services. Under Brazilian law, Flonas are required to prevent disturbance in areas of low timber potential and also to protect forests near rivers and on steep slopes. This results in the maintenance of substantial undisturbed areas that can contribute to the conservation of Amazonian biodiversity (Frumhoff 1995).

In 2000, the Ministry of the Environment launched a new National Forest Program with the goal of establishing at least $400,000 \mathrm{~km}^{2}$ of new Flonas in the Brazilian Amazon. We present here an objective methodology that can be used by national or state governments to identify the best potential areas within the Amazon for establishing new Flonas in a way that maximizes productive capacity and conservation value while minimizing social conflicts.

\section{METHODS}

We used a Geographic Information System (GIS) model to identify areas that are appropriate for designation as National Forests or Florestas Nacionais (Flonas). All GIS data layer integration was done using Arc/Info ${ }^{\mathrm{TM}}$, ArcView ${ }^{\mathrm{TM}}$, and Spatial Analyst ${ }^{\mathrm{TM}}$. The spatial scale of the analysis was 1:2,500,000 (Table 1).

The base area of our analysis was the $5 \times 10^{6} \mathrm{~km}^{2}$ region that the Brazilian government has defined as the Legal Amazon. Locations for potential future Flonas were constrained by excluding existing production reserves (i.e., areas in which sustainable uses such as forest management are allowed), nature reserves (fully protected areas), military bases, and indigenous lands. In accordance with Brazilian law, different levels of activity are allowed in the various classes of protected areas. In cases of overlap, where more than one classification of protection exists, the most restrictive class of protection was used in the subsequent analyses.

There are conflicting views about the land uses that should be permitted in indigenous reservations. Some analyses (Raylands 1991) and institutions (Instituto Socioambiental 1999) classify indigenous reservations as areas that allow human occupation and/or sustainable management activities. This classification is equivalent to the protection afforded to Flonas. However, Brazil's forestry code (Law 4771, Article 3, 
15 September 1965) classifies indigenous reservations as areas of full protection. Therefore, for the purpose of this study, logging was assumed to be prohibited in indigenous reserves.

Table 1. Data used to select potential areas for national forests. Regions of economically viable timber extraction, currently protected lands, nonforested lands, and occupied forest lands were delineated and used to define the possible regions for development. In the "Source" column below, IBGE stands for the Instituto Brasileiro de Geografia e Estatística, Imazon for the Instituto do Homem e Meio Ambiente da Amazônia, ISA for the Instituto Socioambiental, Radam for Projeto RadamBrasil, and INPE for the Instituto Nacional de Pesquisas Espacials.

\begin{tabular}{|c|c|c|c|}
\hline Analysis & Data & Source & Application \\
\hline \multirow[t]{5}{*}{$\begin{array}{l}\text { Economically viable } \\
\text { timber extraction }\end{array}$} & Sawmill centers & Veríssimo et al. (2000) & $\begin{array}{l}\text { Location of centers of wood } \\
\text { production }\end{array}$ \\
\hline & Roads & IBGE (1997) & Assessment of forest access \\
\hline & Navigable rivers & Imazon (1999) & Assessment of forest access \\
\hline & Vegetation & IBGE (1997) & Timber value of the forests \\
\hline & Economic data & Veríssimo et al. (2000) & $\begin{array}{l}\text { Timber value and cost of } \\
\text { production }\end{array}$ \\
\hline Vegetation coverage & Vegetation & IBGE (1997) & Studies of vegetation \\
\hline \multirow[t]{3}{*}{$\begin{array}{l}\text { Protected areas of } \\
\text { the Legal Amazon }\end{array}$} & Conservation units & ISA (1999) & $\begin{array}{l}\text { Areas of prohibited or restricted } \\
\text { use for timber exploration }\end{array}$ \\
\hline & Indigenous lands & ISA (1999) & $\begin{array}{l}\text { Areas of prohibited use for timber } \\
\text { exploration }\end{array}$ \\
\hline & Military areas & ISA (1999) & $\begin{array}{l}\text { Areas of prohibited use for timber } \\
\text { exploration }\end{array}$ \\
\hline Timber potential & Field data & Radam (1973-1978) & Timber potential \\
\hline \multirow[t]{3}{*}{ Human occupation } & County capitals & IBGE (1997) & $\begin{array}{l}\text { Estimate of human occupation in a } \\
20-\mathrm{km} \text { radius }\end{array}$ \\
\hline & Settlements & IBGE (1997) & $\begin{array}{l}\text { Estimate of human occupation in a } \\
10-\mathrm{km} \text { radius }\end{array}$ \\
\hline & Burning & INPE (1998) & $\begin{array}{l}\text { Indicator of human occupation in a } \\
10-\mathrm{km} \text { radius }\end{array}$ \\
\hline
\end{tabular}

The analysis was further constrained by restricting potential designation as Flonas to those forest types with substantial amounts of marketable timber. The base map used for this analysis was the vegetation map issued by the Instituto Brasileiro de Geografia e Estatística (1997). For the purpose of this analysis, closed-canopy, open-canopy, and deciduous forests were classified as suitable forests for potential logging 
activity. Areas that were excluded from consideration included savannas, pioneer vegetation, deforested lands, and transition forests (cerrado-forest).

To avoid social conflicts with local populations and the costs of expropriating inhabited lands, the selection of potential Flonas was restricted to forested areas that had little or no indication of anthropogenic activity. Specifically, a data layer of anthropogenic activity was created that allowed forested areas surrounding known or apparent population centers to be excluded from consideration. Major cities including all county seats (Instituto Brasileiro de Geografia e Estatística 1997) were buffered to a radius of $20 \mathrm{~km}$. Rural settlements (Instituto Socioambiental et al. 1999) were buffered to
$10 \mathrm{~km}$ to reflect the extent of likely forest use (Peres and Terborgh 1995). Furthermore, Advanced Very High Resolution Radiometer (AVHRR) hot-pixel satellite data showing fire locations was used to classify areas of obvious, although unreported, inhabitation. Hot-pixel locations were also buffered to $10 \mathrm{~km}$.

The remaining area after the exclusion of protected areas and areas of current anthropogenic occupation from the base map of forests of possible timber value was used in subsequent analyses. These forests were divided into 61 subsections based on Projeto RadamBrasil's (1973-1978) topographic and hydrologic separations.

Table 2. Transportation cost of round wood and friction coefficients.

\begin{tabular}{lccc}
\hline Type of surface transportation & $\begin{array}{c}\text { Cost } \\
\left.\text { (U.S. } \$ / \mathrm{m}^{3} / \mathrm{km}\right)\end{array}$ & $\begin{array}{c}\text { Friction } \\
\text { coefficient }\end{array}$ & Data source
\end{tabular}

River

Floating logs guided by a boat

Towed barge

Paved road

Large truck

Medium-sized truck

Small truck
0.05

0.01

0.01

0.08

0.01
5

5

5

10

10

10
0.30

0.10

Medium-sized truck

Small truck

0.24
0.60

Truck
Stone (1998)

Veríssimo et al. (1992)

Veríssimo et al. (2000)

Forest trails

Truck

Stone (1998)

Veríssimo et al. (1992)

Barros and Uhl (1995)

Veríssimo et al. (2000) 
A GIS model based on Stone (1998) and Veríssimo et al. (1998) was used to estimate the current extent of potential economically feasible logging. The model calculated the transport cost of timber extraction as a function of transport type (e.g., truck, barge, etc.), transport surface (e.g., paved road, degraded road, unpaved road, logging road, waterway), and distance traveled on each surface type (Table 2). Data layers for the model included vegetation type, road networks (Instituto Brasileiro de Geografia e Estatística 1997), navigable rivers (Instituto do Homem e Meio Ambiente da Amazônia 1999), and logging center locations (Nepstad et al. 1999). Current market values of various timber species (A. Veríssimo et al., unpublished manuscript) and an assumed minimum acceptable profit margin of $15 \%$ were then used to determine the economically viable extraction distances and forest locations for all logging centers. Logging centers were defined as all regions with sawmills that annually consume $>100,000 \mathrm{~m}^{3}$ of timber.

We estimated the forest area necessary to supply continued levels of current annual timber production of approximately $28 \times 10^{6} \mathrm{~m}^{3}$ (Veríssimo and Smeraldi 1999) based on reported areas of extraction of 10,000$15,000 \mathrm{~km}^{2} / \mathrm{yr}$ (Nepstad et al. 1999) and a projected 30 -yr rotation cycle under well-managed production (Amaral et al. 1998).

The conservation values of the remaining forests under consideration were assigned using a map of 385 priority areas for biodiversity conservation (Instituto Socioambiental et al. 1999). This consensus map of high-priority areas for conservation was developed at a meeting of 226 scientists in Macapá, Amapá (September 1999). High-priority areas for conservation were based on species richness, endemism, and deforestation threat.

Fig. 1. Map of legally protected forest areas in the Brazilian Amazon. The map includes areas in which logging is legally prohibited as well as existing areas where managed timber extraction is legally mandated (national forests). In addition to national forests, protected areas include parks and reserves, indigenous lands, and military lands. The extent and percentage of each type of protected area are provided in Table 3.

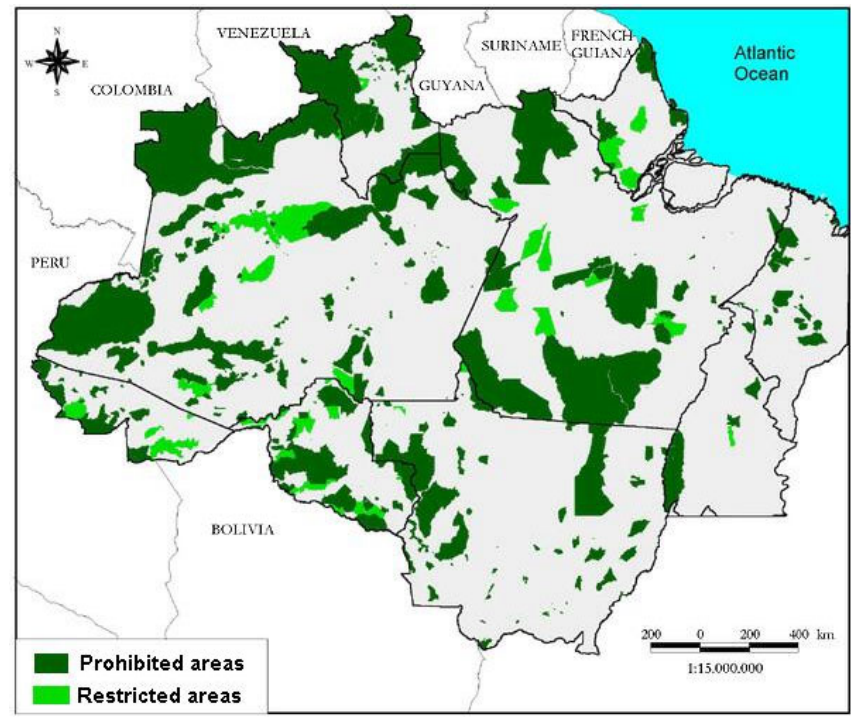

Table 3. Protected areas in the Legal Amazon.

\begin{tabular}{lccc}
\hline Category & $\begin{array}{c}\text { Legal Amazon } \\
\text { (millions of hectares })\end{array}$ & $\begin{array}{c}\text { Legal Amazon } \\
(\% \text { of total) }\end{array}$ & $\begin{array}{c}\text { Legal status of } \\
\text { timber exploration }\end{array}$
\end{tabular}

\begin{tabular}{lccc}
\hline $\begin{array}{l}\text { Parks and reserves } \\
\text { Sustainable use } \\
\quad \text { (national forest) }\end{array}$ & 15 & $3.1 \%$ & Prohibited \\
Indigenous lands & 16 & $3.2 \%$ & Restricted \\
Military lands & 104 & $20.8 \%$ & Prohibited \\
Total & 2 & $0.5 \%$ & Prohibited
\end{tabular}




\section{RESULTS}

Current areas of protection in the Brazilian Amazon comprise approximately $1.4 \times 10^{6} \mathrm{~km}^{2}$ or $28 \%$ of the Amazon. Most of these areas are indigenous reservations (Fig. 1, Table 3). Of the protected regions, only production reserves (3.2\% of Amazonia) currently allow logging. Some $72 \%\left(3.6 \times 10^{6} \mathrm{~km}^{2}\right)$ of the Amazon has no protection and could theoretically be allocated for timber production. However, excluding deforested regions and areas that are naturally without forests $(31 \%)$ indicates that only $41 \%$ of Brazil's Legal Amazon is currently forested and not protected.

The analysis of unprotected forests exhibiting known or likely occupation indicated that $450,000 \mathrm{~km}^{2}(13 \%)$ of forests are currently occupied and should be excluded from consideration (Fig. 2). The analysis excluded all forests within $20 \mathrm{~km}$ of 832 county seats $\left(131,000 \mathrm{~km}^{2}\right)$ as well as all forests within $10 \mathrm{~km}$ of 822 smaller communities $\left(46,000 \mathrm{~km}^{2}\right)$ containing a total of approximately 500,000 people. The remaining excluded area $\left(273,000 \mathrm{~km}^{2}\right)$ resulted from the more than 30,000 Advanced Very High Resolution Radiometer (AVHRR) hot pixels that indicate likely human presence.

Fig. 2. Map of forests in Brazil's Legal Amazon with indications of areas known or suspected to be occupied or frequently used by the resident Amazonian population.

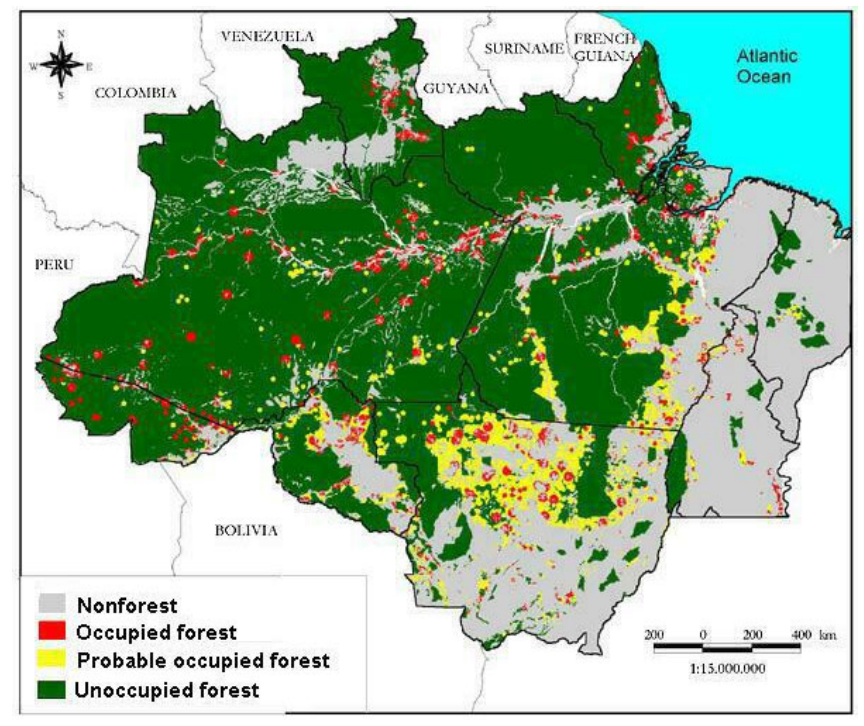

We also excluded $50,000 \mathrm{~km}^{2}$ of forested areas with very low timber value from consideration for Flona designation. Assessments of expected values of timber stocks were based on forest inventory data from
Projeto RadamBrasil (1973-1978).

The elimination of protected areas, forest cover, human occupation, and areas of low timber values still left approximately $1.55 \mathrm{x} \quad 10^{6} \mathrm{~km}^{2} \quad(46 \%)$ of Amazonian forest for consideration as potential Flonas. However, not all of this forest would be economically feasible to harvest. With the existing infrastructure, approximately $400,000 \mathrm{~km}^{2}(12 \%)$ of the forest is too remote to be of economic value to logging companies (Fig. 3). These remote forested areas are located primarily in western Amazonas and Acre and in the extreme northern reaches of Amazonas, Pará, and Amapá.

Fig. 3. Map of all unoccupied forests in the Brazilian Amazon. Potential national forests or Florestas Nacionais (Flonas) have enough timber resources and accessibility to be profitably used under best management practices. Economically inaccessible forests are either too distant or too difficult to reach to provide reasonable profits.

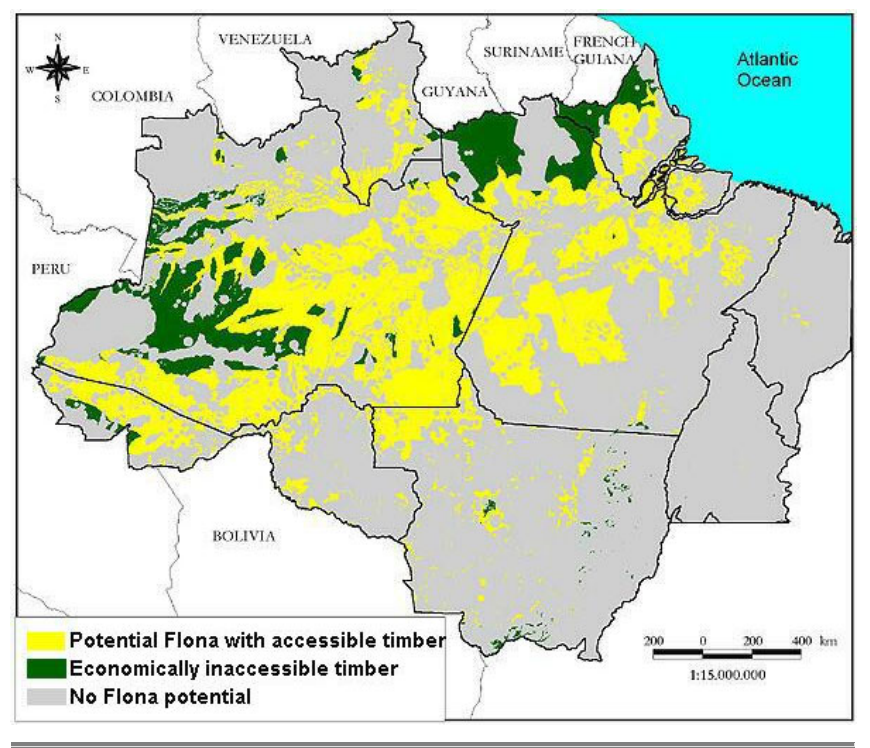

Our analysis showed that the remaining $1.15 \times 10^{6} \mathrm{~km}^{2}$ (34\% of Amazon forests) of forested area under consideration had no official protection and a low level of human occupation, and was economically feasible for timber extraction. These forests could be considered for potential incorporation as sustainable production forests in Brazil's Flona system. Furthermore, superposition of the potential Flona and high-priority conservation (Instituto Socioambiental et al. 1999) maps revealed that $38 \%$ of the potential area for Flonas $\left(437,000 \mathrm{~km}^{2}\right)$ was also of high biodiversity conservation priority (Fig. 4). The complete results of these analyses are given in Table 4. 
Table 4. Distribution of units mapped using a Geographic Information System model to determine the area of the Brazilian Amazon still available for national forests or Florestas Nacionais (Flonas).

\begin{tabular}{lc}
\hline Type of area & Area in $\mathrm{km}^{2}$ \\
\hline Brazilian Amazon & $5,000,000$ \\
Protected & $1,200,000$ \\
Nonforest & $1,550,000$ \\
Unprotected & $3,600,000$ \\
Forest & $2,050,000$ \\
Occupied & 450,000 \\
County seats & 131,000 \\
Rural communities & 46,000 \\
Probably occupied & 273,000 \\
Low timber value & 50,000 \\
Economically unviable & 400,000 \\
High conversation priority & 437,000 \\
Potential Flonas & 713,000 \\
\end{tabular}

\section{DISCUSSION}

Our results revealed that there were sufficient unoccupied and unprotected forest reserves in the Amazon to establish a network of Flonas that would be capable of supplying enough managed production to meet present and expected demands for Amazon timber. If the Brazilian government acts now to incorporate these areas into its system of Flonas, it can do so with a minimum of social conflicts or protests from conservationists. Furthermore, by acting now, the government can capture a greater portion of the rents for extracted resources and put in place the control and management measures needed to sustain these vast natural resources.

Stabilization of the wood sector will require the adoption of forest management in both public and private areas. The unsustainable mining of resources from forests on private land around older logging centers has caused sawmills to migrate to unoccupied lands in the west of Pará and southeast of Amazonas.
In these regions, the government should try to prevent a repetition of the predatory model of resource use and the privatization of public lands. The most promising alternative lies in the creation of Flonas (Schneider et al. 2000).

Because the current perception of timber abundance is generating transient boom-and-bust economic activity, strategic expansion of the Flona system could contribute to both biodiversity conservation and economic stability in the Amazon by constraining unsustainable development activities. In tropical countries, protected areas, even those with insufficient funding and manpower, have proven to be surprisingly effective in reducing deforestation and other forms of degradation (Bruner et al. 2001). The establishment of a more expansive system of Flonas could be instrumental in reducing the negative impacts of development programs such as Avança Brasil and dramatically alter the dire predictions of future forest destruction and degradation based on current predatory models of development (Laurance et al. 2001). 
Fig. 4. Map of all the forests in the Brazilian Amazon that could be designated as national forests or Florestas Nacionais (Flonas). Highlighted are potential Flona forests that were chosen by 226 scientists as a high priority for conservation at a conference in September 1999 (Instituto Socioambiental 1999). There are still $700,000 \mathrm{~km}^{2}$ of potential Flonas that could provide a matrix of working forests to link regions of protection and high biodiversity.

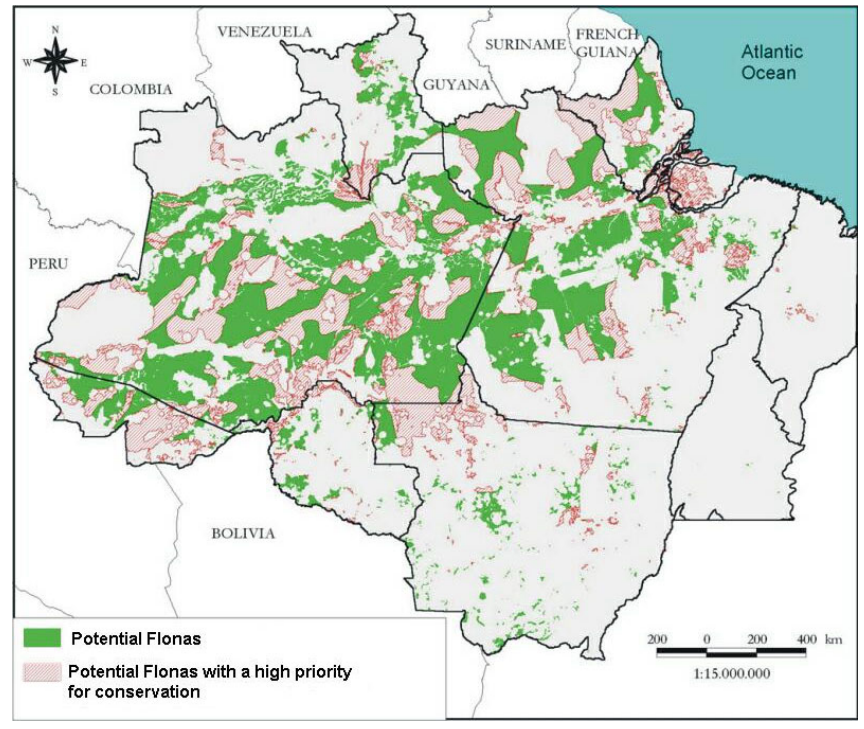

Flonas will be important for the conservation of biodiversity in the Amazon. Current conservation goals call for the protection of $10-12 \%$ of tropical forests. Even if this goal can be achieved, it will mean the extinction of $50 \%$ or more of all species (Soule and Sanjayan 1998). Establishing the suggested Flonas would protect $14 \%$ of the Brazilian Amazon from deforestation. This, combined with Brazil's other conservation lands, would easily make the country of Brazil one of the foremost conservers of natural resources in the world.

Production forests such as Flonas are an essential complement to protected parks in an overall conservation strategy (Cabarle 1998). Production forests have previously been suggested as supplemental reserves for wildlife conservation (Frumhoff 1995), and conserving wildlife is also considered necessary for the long-term management of naturally regenerating forests (Robinson et al. 1999). For this reason, a combination of biodiversity conservation and best management practices is needed to establish truly sustainable production. The protection of areas of high biological significance will require the creation of a mosaic of conservation areas that combines Flonas (sustainable use) with parks and biological reserves (full protection). In this system, Flonas would form a buffer zone around parks and reserves. In addition, Flonas could also provide corridors for the movement of species between core protection areas.

With the goal of realizing this potential for the creation of such a land-use mosaic, we combined the maps of areas that had the potential to be designated as national forests with the map of 385 priority areas for biodiversity conservation developed at a meeting of 226 scientists in Macapá, Amapá, in September 1999 (Instituto Socioambiental et al. 1999). The superposition of these maps revealed that $38 \%$ of the potential Flonas $\left(437,000 \mathrm{~km}^{2}\right)$ were located in areas with a high priority for biodiversity conservation (Fig. 4). When we excluded the common overlay areas from consideration as potential Flonas on the assumption that, in this case, the best option will be to fully protect these areas, the remaining area was still approximately $700,000 \mathrm{~km}^{2}$ in size (Fig. 4). This demonstrates the complementary potential of policies based on sustainable forest use and biodiversity conservation.

\section{CONCLUSION}

Establishing the necessary sustainable production forests to provide for long-term tropical timber extraction is only one step toward achieving a truly sustainable management system. It is, however, the first crucial step, and it is critical that these forests be established now before economic and social factors make such action politically unfeasible. This research shows that there are still substantial amounts of forest that can be incorporated into Flonas with little or no conflict with current protected areas or land occupiers. Current levels of timber production could be sustainably produced within $700,000-800,000 \mathrm{~km}^{2}$ of Flonas, even if half of the available area is permanently conserved. In fact, it would be possible to increase current timber production levels while simultaneously protecting vast amounts of Amazonian forest. There will inevitably be questions about the level of enforcement of regulations in sustainable management forests (Gascon et al. 1998). The boomand-bust nature of tropical logging operations has often been blamed on external factors, but, for the most part, it is a function of the tropical country's own policies (Vincent 1992). Brazil ultimately has to decide whether to manage its vast natural resources well or follow the all too familiar boom-and-bust pattern. 
The proposed method for siting Flonas in the Brazilian Amazon may provide a model for the resolution of similar complex land-use problems in other countries where many factors and constituencies must be taken into account in decision making. In the case of the Amazon, we feel that the creation of the suggested Flonas may provide the last best chance for Brazil, and the world, to develop a large-scale sustainable management system for tropical forests while simultaneously providing substantial conservation of biodiversity and environmental services.

Responses to this article can be read online at: http://www.consecol.org/vol6/iss 1/art4/responses/index.html

\section{Acknowledgments:}

We gratefully acknowledge Christopher Uhl, Paulo Barreto, Newton Zerbini, and Raimundo Deusdará Filho for their comments on previous manuscript drafts and the Ministerio do Meio Ambiente do Brasil (MMA), Programa de Pesquisa Dirigida (PPD-PPG7-FINEP), and WWF Brazil for their financial support.

\section{LITERATURE CITED}

Amaral, P., A., Veríssimo, P. Barreto, and E. Vidal. 1998. Floresta para sempre: um manual para produção de madeira na Amazônia. Instituto do Homem e Meio Ambiente da Amazônia, Belém, Brazil.

Barreto, P., P. Amaral, E. Vidal, and C. Uhl. 1998. Costs and benefits of forest management for timber production in eastern Amazonia. Forest Ecology and Management 108:926.

Barros, A. C., and C. Uhl. 1995. Logging along the Amazon River and estuary: patterns, problems and potential. Forest Ecology and Management 77:87-105.

Bruner, A. G., R. E. Gullison, R. E. Rice, and G. A. B. da Fonseca. 2001. Effectiveness of parks in protecting tropical biodiversity. Science 291:125-128.

Cabarle, B. J. 1998. Logging on in the rain forests. Science 281:1453-1454.

Cochrane M. A., A. Alencar, M. D. Schulze, C. M. Souza Jr., D. C. Nepstad, P. Lefebvre, and E. A. Davidson. 1999. Positive feedbacks in the fire dynamic of closedcanopy tropical forests. Science 284:1832-1835.

Cochrane, M. A., and Schulze, M. D. 1999. Fire as a recurrent event in tropical forests of the eastern Amazon: effects on forest structure, biomass, and species composition. Biotropica 31:2-16.

Frumhoff, P. C. 1995. Conserving wildlife in tropical forests managed for timber. BioScience 45:456-464.

Gascon, C., R. Mesquita, and N. Higuchi. 1998. Logging on in the rain forests. Science 281: 1453.

Holdsworth, A. R., and C. Uhl. 1997. Fire in Amazonian selectively logged rain forest and the potential for fire reduction. Ecological Applications 7:713-725.

Houghton, R. A. 1995. Land-use change and the carboncycle. Global Change Biology 1:275-287.

Houghton, R. A., D. L. Skole, C. A. Nobre, J. L. Hackler, K. T. Lawrence, and W. H. Chomentowski. 2000. Annual fluxes of carbon from deforestation and regrowth in the Brazilian Amazon. Nature 403:301-304.

Instituto Brasileiro de Geografia e Estatística. 1997. Diagnóstico ambiental da Amazônia Legal. IBGE/DGC/DERNA-DEGEO-DECAR, Rio de Janeiro, Brazil.

Instituto do Homem e Meio Ambiente da Amazônia. 1999. Mapa de rios navegáveis da Amazônia Legal. Instituto do Homem e Meio Ambiente da Amazônia, Belém, Brazil.

Instituto Nacional de Pesquisas Espaciais. 1998. Queimadas no Brasil, dados oficiais. Instituto Nacional de Pesquisas Espaciais, São José dos Campos, Brazil. Available online at: http://www.cptec.inpe.br/ products/queimadas/queimap.html.

Instituto Socioambiental. 1999. Mapa de areas protegidas da Amazônia Legal. Instituto Socioambiental, São Paulo, Brazil.

Instituto Socioambiental, Instituto do Homem e Meio Ambiente da Amazônia, Instituto de Pesquisa Ambiental da Amazônia, Instituto Sociedade População e Natureza, Grupo de Trabalho Amazônico, and Conservation International. 1999. Seminário Consulta de Macapá 99: avaliação e identificação de ações prioritárias para a conservação, utilização sustentável e repartição dos benefícios da biodiversidade na Amazônia. Instituto Socioambiental, São Paulo, Brazil.

Johns, J. S., P. Barreto, and C. Uhl. 1996. Logging damage in planned and unplanned logging operations in the eastern Amazon. Forest Ecology and Management 89:5977.

Laurance, W. F., M. A. Cochrane, S. Bergen, P. M. Fearnside, P. Delamônica, C. Barber, S. d'Angelo, and T. Fernandes. 2001. The future of the Brazilian Amazon: development trends and deforestation. Science 291:438-439.

Martini, A., N. Rosa, and C. Uhl. 1994. An attempt to 
predict which Amazonian tree species may be threatened by logging activities. Environmental Conservation 21:152-162.

Nepstad D. C., A. Veríssimo, A. Alencar, C. Nobre, E. Lima, P. Lefebvre, P. Schlesinger, C. Potter, P. Moutinho, E. Mendoza, M. A. Cochrane, and V. Brooks. 1999. Large-scale impoverishment of Amazonian forests by logging and fire. Nature 398:505-508.

Peres, C., and J. Terborgh. 1995. Amazonian nature reserves: an analysis of the defensibility status of existing conservation units and design criteria for the future. Conservation Biology 9:34-46.

Projeto RadamBrasil. 1973-1978. Levantamento de recursos naturais. Volumes 1-16. Ministerio das Minas e Energia, Departamento Nacional da Produção Mineral, Rio de Janeiro, Brazil.

Raylands, A. B. 1991. The status of conservation areas in the Brazilian Amazon. World Wildlife Fund, Washington, D.C., USA.

Robinson, J. G., K. H. Redford, and E. L. Bennett. 1999. Wildlife harvest in logged tropical forests. Science 284:595596.

Salati, E., and P. B. Vose. 1984. Amazon basin: a system in equilibrium. Science 225:129-138.

Schneider, R., E. Arima, A. Veríssimo, P. Barreto, and C. Souza Jr. 2000. Amazônia sustentãvel: limitantes e oportunidades para o desenvolvimento rural. Série Parcerias Number 1. World Bank and Instituto do Homem e Meio Ambiente da Amazônia, Brasília, Brazil.

Shukla, J., C. Nobre, and P. Sellers. 1990. Amazon deforestation and climate change. Science 247:1322-1325.

Skole, D., and C. J. Tucker. 1993. Tropical deforestation and habitat fragmentation in the Amazon: satellite data from 1978 to 1988. Science 260:1905-1910.

Soulé, M. E., and M. A. Sanjayan. 1998. Conservation targets: do they help? Science 279:2060-2061.

Stone, S. W. 1998. Using a geographic information system for applied policy analysis: the case of logging in the Eastern Amazon. Ecological Economics 27:43-61.

Uhl, C., P. Barreto, A. Veríssimo, E. Vidal, P. Amaral, A. C. Barros, C. Souza, J. Johns, and J. Gerwing. 1997. Natural resource management in the Brazilian Amazon. Bioscience 47:160-168.

Uhl, C., and R. Buschbacher. 1985. A disturbing synergism between cattle ranch burning practices and selective tree harvesting in the Eastern Amazon. Biotropica 17:265-268.

Uhl, C., and J. B. Kauffman. 1990. Deforestation, fire susceptibility, and potential tree responses to fire in the eastern Amazon. Ecology 71:437-449.

Uhl, C., and I. C. G. Vieira. 1989. Ecological impacts of selective logging in the Brazilian Amazon: a case study from the Paragominas region of the State of Para. Biotropica 21:98-106.

Veríssimo, A., and P. Amaral. 1998. Forestry in the Amazon: current situation and prospects. Pages 265-276 in D. E. Leihner and T. A. Mitschein, editors. Proceedings of the Conference, a Third Millenium for Humanity? The search for paths of sustainable development. Europäischer Verlag der Wissenschaften, Frankfurt/Main, Germany.

Veríssimo, A., P. Barreto, M. Mattos, R. Tarifa, and C. Uhl. 1992. Logging impacts and prospects for sustainable forest management in an old Amazonian frontier: the case of Paragominas. Forest Ecology and Management 55:169-199.

Veríssimo, A., P. Barreto, R. Tarifa, and C. Uhl. 1995. Extraction of a high-value natural source from Amazon: the case of mahogany. Forest Ecology and Management 72:3960.

Veríssimo, A., and R. Smeraldi. 1999. Acertando o alvo: consumo de madeira no mercado interno brasileiro $e$ promoção da certificação florestal. Instituto do Homem e Meio Ambiente da Amazônia, Amigos da Terra, and Imaflora, São Paulo, Brazil.

Veríssimo, A., C. M. Souza Jr., S. Steve, and C. Uhl. 1998. Zoning of timber extraction in the Brazilian Amazon. Conservation Biology 12:128-136.

Veríssimo, A., C. M. Souza Jr., and E. Lima. 2000. Bases para o zoneamento da atividade madeireira na Amazônia Legal. Instituto do Homem e Meio Ambiente da Amazônia, Belém, Brazil.

Vincent, J. R. 1992. The tropical timber trade and sustainable development. Science 256:1651-1655. 